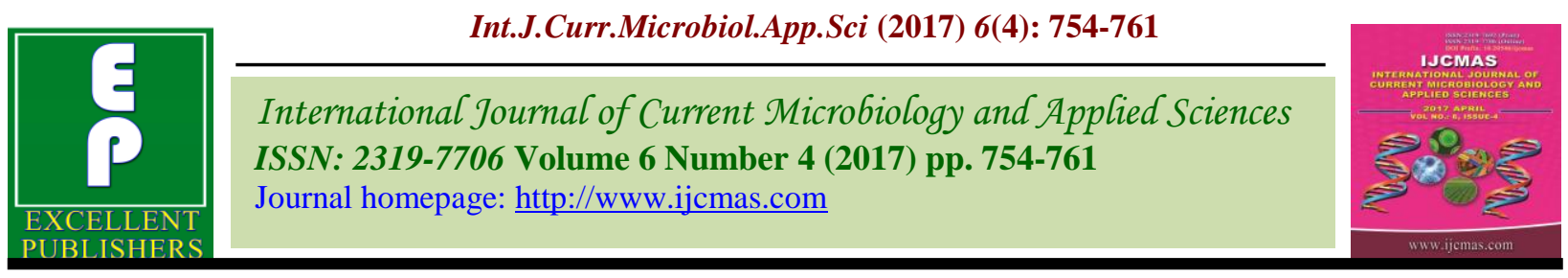

Original Research Article

https://doi.org/10.20546/ijcmas.2017.604.093

\title{
Effect of Different Intercrops on Growth and Yield Attributes of American Cotton under Dryland Condition
}

\author{
Ravindra Kumar ${ }^{1}$, A.B. Turkhede ${ }^{1}$, R.K. Nagar $^{1}$ and Anil Nath ${ }^{2} *$ \\ ${ }^{1}$ Department of Agronomy, Dr. Panjabrao Deshmukh Krishi Vidyapeeth, Akola, \\ Maharastra-444 104, India \\ 2 Department of Agronomy,G.B.P.U.A. \& T., Pantnagar,UK-263145, India \\ *Corresponding author
}

\begin{tabular}{|c|c|}
\hline & A B T R A C T \\
\hline $\begin{array}{l}\text { rcrops, Growth } \\
1 \text { Yield attribute, } \\
\text { yland }\end{array}$ & \multirow{3}{*}{$\begin{array}{l}\text { A field experiment was conducted to find out the effect of different intercrops on growth } \\
\text { and yield attributes of American cotton under dryland condition during kharif season of } \\
2014-15 \text { at the farm of AICRP for Dryland Agriculture, Dr. Panjabrao Deshmukh Krishi } \\
\text { Vidyapeeth, Akola (Maharashtra). The experiment was laid out in randomized block } \\
\text { design, replicated thrice with eleven treatments. Maximum plant height }(71.23 \mathrm{~cm}) \text {, leaf } \\
\text { area }\left(1462 \mathrm{~cm}^{2}\right) \text { and leaf area index }(0.81) \text { were recorded in cotton }+ \text { clusterbean } \\
\text { intercropping system than other cropping system. While maximum number of monopodial } \\
(2.33) \text {, number of sympodial }(15.33) \text {, number of functional leaves }(46.69) \text {, total dry matter } \\
\text { accumulation }(70.86 \mathrm{~g}) \text {, number of picked bolls per plant }(8.93), \text { boll weight }(2.88 \mathrm{~g}) \text {, seed } \\
\left.\text { cotton yield plant }{ }^{-1} \text { ( } 26.51 \mathrm{~g}\right) \text { and Seed cotton yield }\left(1266 \mathrm{~kg} \mathrm{ha}^{-1}\right) \text { were recorded } \\
\text { significantly in sole cotton. Seed cotton equivalent yield }\left(1958 \mathrm{~kg} \mathrm{ha}^{-1}\right) \text { and land equivalent } \\
\text { ratio }(1.46) \text { was recorded highest in cotton }+ \text { cowpea. }\end{array}$} \\
\hline Article Info & \\
\hline $\begin{array}{l}06 \text { March } 2017 \\
\text { Available Onlir } \\
10 \text { April } 2017\end{array}$ & \\
\hline
\end{tabular}

\section{Introduction}

Cotton (Gossypium sp.) is one of the most important fibre and cash crop in India belongs to Malvaceae family and known as "King of Fiber" and "White gold" plays a prominent role in the rural, national and international economy. It is grown mostly for fibre used in the manufacture of cloths for mankind. In recent years, cotton apparels are being preferred to the synthetic ones due to the increasing the health consciousness among the people. Besides fibre, cotton is also valued for its oil (15 - 20\%) which are used as vegetable oil and soap industries and cotton seed cake is very protein rich cotton seed cake used as cattle feed and as manure which contain $6.4,2.9$ and 2.2 per cent $\mathrm{N}, \mathrm{P}$ and $\mathrm{K}$, respectively. India is a major producer of cotton. India stands first position in area and third in its production. In India it is grown over an area of 115.13 lakh hectares with production of 375 lakh bales and productivity of $489 \mathrm{~kg} / \mathrm{ha}$ (Anonymous, 2013). Intensification of cotton based cropping system with intercrops was successful as a components in the system have different nutrient and moisture requirement, varied feeding zones in the soil profile, differential growth duration for enabling the utilization of natural resources optimally (Sankaranarayanan et al., 2011). 
Intercropping has been recognized as potentially beneficial and economic system of crop production. Similarly intercropping is one of the ways to increase the cropping intensity and resource utilization (Harisudan et al., 2008). Usually a yield advance occurs as component crop differ in their use of resources when they are grown in combination, they are able to component each other and make better use of resources.

Due to slow growing nature of cotton much of the vacant interspaces remains utilized during initial stages of the crop growth. This situation offers ample scope for raising intercrops (Nehra et al., 1990). Similarly, this situation can be advantageously exploited for intercropping for short. Due to the early maturing pulses like blackgram, greengram, and clusterbean, which improve the fertility status of soil (Muruganandam, 1984). Intercropping with the crops provides the insurance against the inclement weather situation and consequent crops (Balasubramanian, 1987; Sivakumar, 2003) observed increase in productivity with higher market value and enhanced profitability when pulses were intercropped with cotton. Intercropping of legumes is an important aspect for biological farming system not only for weed control, but also in reducing the leaching of nutrients, pest control and in reducing soil erosion (Prabukumar and Uthayakumar, 2006). Keeping all the views in mind an experiment was conducted to find out the effect of different intercrops on growth and yield attributes on American cotton under dryland condition.

\section{Materials and Methods}

A field experiment was conducted during kharif season of 2014 at the farm of AICRP for Dryland Agriculture, Dr. Panjabrao Deshmukh Krishi Vidyapeeth, Akola (Maharashtra) which is geographically located at north latitude of $22042^{\prime}$ and East longitudes of 770 2' and at an altitude of $307.42 \mathrm{~m}$ above mean sea level. The soil of experimental plot was clayey in texture, slightly alkaline in reaction, medium in organic carbon and in available nitrogen and low in available phosphorus but having fairly rich status of available potassium. During kharif season of 2014-15, the total rainfall received was $588.2 \mathrm{~mm}$ in 32 rainy days. The experiment was laid out in randomized block design, replicated thrice with eleven treatments viz., Sole cotton, Sole greengram, Sole blackgram, Sole soybean, Sole clusterbean, Sole cowpea, Cotton + greengram (1:1), Cotton + blackgram (1:1), Cotton + soybean $(1: 1)$, Cotton + clusterbean (1:1) and Cotton + cowpea (1:1). Five plants in each treatment in the net plot area were selected at random and tagged for biometric observations. While taking observations, five plants from sampling rows were pulled off in each treatment plot for recording dry matter production. The intercrops were incorporated within the interspaces after picking of pods of intercrops. The statistical analysis was done as per procedure suggested by Gomez and Gomez (1984).

\section{Results and Discussion}

\section{Growth attributes}

In this experiment, intercropping with different crops shows that growth attributes viz. (plant height, number of sympodial, number of functional leaves and total dry matter accumulation) of cotton were influenced significantly but number of monopodial, Leaf area and leaf area index of cotton were not influenced significantly. Maximum plant height $(71.23 \mathrm{~cm})$, Leaf area $\left(1462 \mathrm{~cm}^{2}\right)$ and leaf area index $(0.81)$ were recorded in cotton + clusterbean intercropping system than other cropping system. Tallness in the plots of intercrops of clusterbean and 
cowpea might be associated with competitive effect for space, moisture, nutrient and light (due to Annidation process) further accelerated the phototropism and thereby increased plant height of cotton. Similarly, observations of increased plant height in cotton due to different intercrops were reported by Wankhade et al., (2000), Deoche (2001), Kalyankar (2001), Hallikeri et al., (2005), Srivastava et al., (2010) and Satish et al., (2012) and Shankarnarayan et al., (2012). Whereas, sole cotton recorded significantly maximum number of monopodial (2.33), number of sympodial (15.33), number of functional leaves (46.69) and total dry matter accumulation (70.86 g) over intercropping system. The lesser number of monopodial, sympodial, number of functional leaves and total dry matter accumulation in the treatment plots of intercrop were due to competition of these intercrops for growth factors along with the crop of cotton. These results are in conformity with the work of Wankhade et al., (2000), Deoche (2001), Kalyankar (2001), Hallikeri et al., (2005) and Shrivastava et al., (2010) and Sankaranarayanan et al., (2011).

\section{Yield attributes}

Sole cotton recorded significantly higher number of picked bolls per plant than the rest of the treatments. Treatments of various cotton + intercrops viz. (cotton + greengram, Cotton + blackgram, Cotton + Soybean, Cotton + Clusterbean, and Cotton + Cowpea) were being at par produced comparable number of picked bolls per plant.

Mean boll weight was (2.86 g), the boll weight was not affected significantly due to different treatments of intercrop.

Treatment of sole cotton resulted in higher production of seed cotton yield per plant over other treatments. Treatments of intercrop of cotton + intercrops (i.e. greengram, blackgram, clusterbean, soybean and cowpea) were at par recorded greater production of seed cotton yield per plant. Thus, intercropping with cotton was successful as a component because of cotton has different nutrient and moisture requirements, varied feeding zones in the soil profile, differential growth duration for enabling the utilization of natural resources optimally. Number of bolls plant $^{-1}$, seed cotton yield plant ${ }^{-1}$ was highest in sole cotton than intercropped with greengram, blackgram, soybean, vegetables likes clusterbean, cowpea, etc. as well as weight of seed cotton per boll was not significantly influenced by intercropping also reported by Wankhade et al., (2000), Deoche (2001), Khan et al., (2001), Sanjay et al., (2003), Halemani et al., (2004), Venkataraman (2008), Shrivastava et al., (2010) Satish et al., (2012) and Khargkharate et al., (2014).

\section{Effect on yield}

Treatment sole cotton recorded significantly higher seed cotton yield (1266 $\left.\mathrm{kg} \mathrm{ha}^{-1}\right)$ than the rest of treatments because of number of rows per plot were higher than intercropping treatments, while various intercropping treatments recorded lower seed cotton yield than Sole cotton due to less no. of rows to the sole cotton plot. However, among the treatments of various intercropping system, cotton + clusterbean $(1: 1)$ recorded significantly higher seed cotton yield (1139 $\mathrm{kg} \mathrm{ha}^{-1}$ ) and found being at par with rest of the treatments of intercropping. Due to wider row spacing of cotton $90 \times 20 \mathrm{~cm}$ and duration of the different vegetables intercrops, none of the above crops competed with the main crop of cotton during the growth and development. This might be attributed to the uniform duration of these intercrops. These results are in the line of work reported by Rami Reddy (2005), Hallikeri et al., (2007), Rekha et al., (2008), Mankar and Nawlakhe (2009), Sankaranarayanan et al., (2012) and Khargkharate et al., (2014). 
Table.1 Plant height $(\mathrm{cm})$, no. of monopodial plant ${ }^{-1}$, no. of sympodial plant $t^{-1}$, no. of functional leaves plant ${ }^{-1}$, leaf area index and total dry matter accumulation plant $^{-1}(\mathrm{~g})$ of cotton as influenced by different treatments

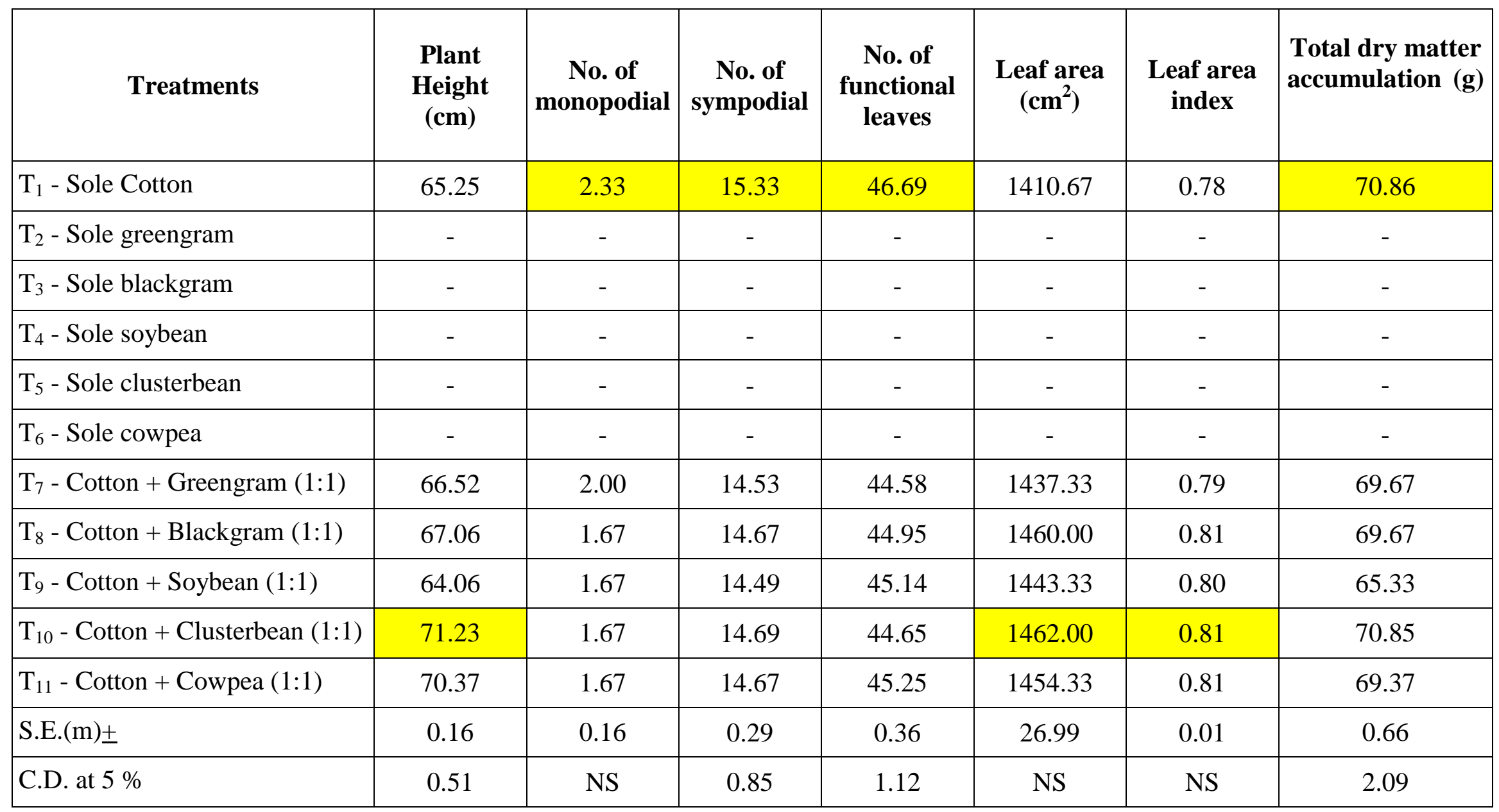


Table.2 Number of picked bolls plant ${ }^{-1}$, boll weight and seed cotton yield plant ${ }^{-1}$ of cotton as influenced by different treatments

\begin{tabular}{|c|c|c|c|c|c|c|c|}
\hline Treatments & $\begin{array}{c}\text { Number of } \\
\text { picked bolls } \\
\text { plant }^{-1}\end{array}$ & $\begin{array}{c}\text { Boll } \\
\text { weight (g) }\end{array}$ & $\begin{array}{l}\text { Seed cotton } \\
\text { yield plant } \\
\text { (g) }\end{array}$ & $\begin{array}{c}\text { Seed cotton } \\
\text { yield } \\
\left(\mathrm{kg} \mathrm{ha}^{-1}\right)\end{array}$ & $\begin{array}{c}\text { Intercrop } \\
\text { yield } \\
\left(\mathbf{k g ~ h a}^{-1}\right)\end{array}$ & $\begin{array}{c}\text { Seed cotton } \\
\text { equivalent } \\
\text { yield } \\
\left(\mathrm{kg} \mathrm{ha}^{-1}\right)\end{array}$ & $\begin{array}{c}\text { Land } \\
\text { Equivalent } \\
\text { Ratio }\end{array}$ \\
\hline $\mathrm{T}_{1}-$ Sole Cotton & 8.93 & 2.88 & 26.51 & 1266 & - & 1266 & 1.00 \\
\hline $\mathrm{T}_{2}$ - Sole greengram & - & - & - & - & 2090 & 880 & 1.00 \\
\hline $\mathrm{T}_{3}$ - Sole blackgram & - & - & - & - & 493 & 787 & 1.00 \\
\hline $\mathrm{T}_{4}$ - Sole soybean & - & - & - & - & 1086 & 915 & 1.00 \\
\hline $\mathrm{T}_{5}$ - Sole clusterbean & - & - & - & - & 3346 & 1409 & 1.00 \\
\hline $\mathrm{T}_{6}$ - Sole cowpea & - & - & - & - & 3466 & 1460 & 1.00 \\
\hline $\mathrm{T}_{7}-$ Cotton + Greengram $(1: 1)$ & 7.40 & 2.88 & 22.36 & 1048 & 872 & 1484 & 1.25 \\
\hline $\mathrm{T}_{8}-$ Cotton + Blackgram $(1: 1)$ & 7.60 & 2.87 & 22.41 & 1039 & 243 & 1494 & 1.30 \\
\hline $\mathrm{T}_{9}-$ Cotton + Soybean $(1: 1)$ & 7.29 & 2.87 & 21.89 & 992 & 492 & 1406 & 1.23 \\
\hline $\mathrm{T}_{10}-$ Cotton + Clusterbean $(1: 1)$ & 7.46 & 2.87 & 22.40 & 1139 & 1881 & 1931 & 1.46 \\
\hline $\mathrm{T}_{11}-$ Cotton + Cowpea $(1: 1)$ & 7.79 & 2.87 & 22.90 & 1114 & 2004 & 1958 & 1.46 \\
\hline S.E.(m) \pm & 0.18 & 0.02 & 0.51 & 40.3 & - & 46.1 & 0.05 \\
\hline C.D. at $5 \%$ & 0.57 & NS & 1.61 & 126 & - & 136.1 & 0.13 \\
\hline
\end{tabular}


Fig.1 Seed cotton yield ( $\mathrm{kg} \mathrm{ha-1)} \mathrm{and} \mathrm{seed} \mathrm{cotton} \mathrm{equvalient} \mathrm{yield} \mathrm{(} \mathrm{kg}$ ha-1) as influenced by various tratments

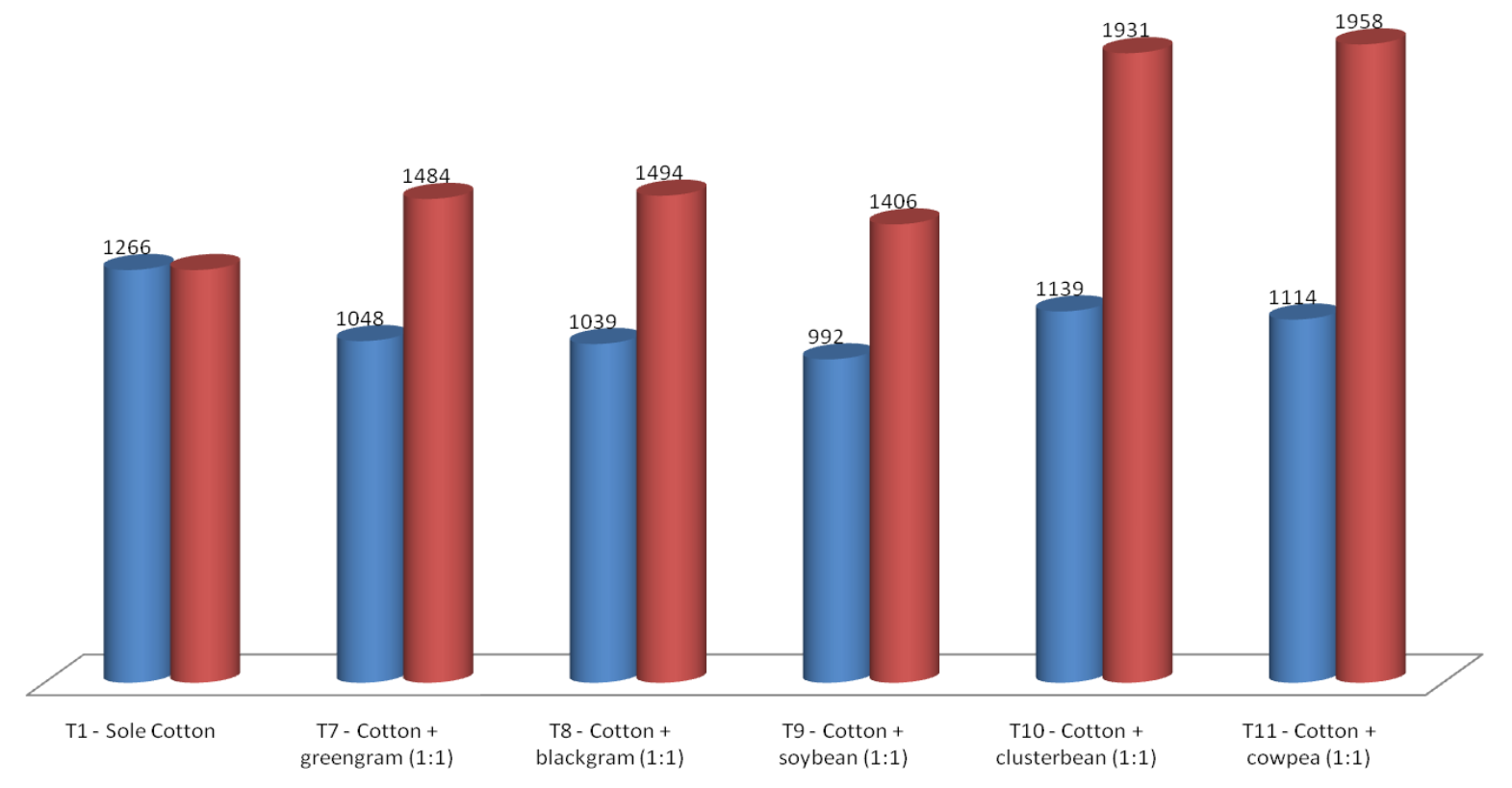

Intercrop cotton + cowpea and cotton + clusterbean were being at par recorded significantly higher seed cotton equivalent yield than the rest of the treatments (Tables 1 and 2). In general, the trend of cotton seed equivalent yield in different treatments plots of intercrop was consistent (Fig. 1). However, seed cotton equivalent yield increased due to different intercrops over sole crop of cotton. This is attributed to better productivity of variety AKH-9916 of cotton and intercrops of cowpea and clusterbean and their remunerative market prices. When cotton intercropped with blackgram, greengram soybean, clusterbean, etc. the higher average seed cotton yield equivalent recorded in intercropping system than sole cotton because of yield of intercrops were higher than their sole treatments, the marker price was also higher and Clusterbean, greengram and cowpea were used as vegetable purpose so, also reported by the workers by Prasad et al., (2000) at New Delhi, Chellaiah and Gopalswamy (2001) at Srivilliputtur (T.N.), Kalyankar (2001) at Parbhani, Nandini and
Chellamuthu (2004) at Dharwad, Venkataraman, (2008) at Kovilpatti (T.N.).

\section{Effect on land equivalent ratio}

Treatments of intercrops of cotton + clusterbean and cotton + cowpea were at par recorded greater values of land equivalent ratio and significantly superior than rest of the intercropping treatments. However, cotton + greengram and cotton + blackgram and cotton + soybean were at par than sole cotton and sole cotton recorded lowest value of land equivalent ratio. It indicated that whether association is more beneficial than sole treatment and also indicated which crop is not suitable for association so that the association of such crops may be avoided. Singh et al., (2000), Chittapur (2004), Nandini and Chellamuthu (2004), Rami Reddy and Shaik Mohammad (2009) Velmurugan et al., (2012 and 2013) were reported that the LER was higher under intercropping system than their respective sole crops. 


\section{References}

Anonymous. 2013. The cotton corporation India Lt. http://www.cotcorp. gov.in/statistics.aspx htt.

Balasubramanian, T.N. 1987. Ph.d Thesis. Tamil Nadu Agric. Univ., Coimbatore, India.

Chellaiah, N. and G.N. Gopalaswamy. 2001. Effect of intercropping and foliar nutrition on the productivity of summer irrigated cotton. Madras Agric. J., 87(4): 267-270.

Chittapur, B.M. 2004. Cotton based cropping systems for sustainable productivity. International symposium on "Strategies for sustainable cotton production - A global vision" 2. crop production, University of Agricultural sciences, Dharwad, Karnataka (INDIA): 45-55.

Deoche, S.A. 2001. Studies on intercropping in extra early hirsutum cotton genotype AKH-081. M.Sc. (Agric.) Thesis submitted to Dr. PDKV Akola.

Gomez, K.A. and Gomez, A.A. 1984. Statistical procedure for Agricultural Research. An International Rice Research Institute Book. A Willey Inter Science Publication, New York.

Halemani, H.L., S.S. Haikeri, S.S. Nooli, R.A. Nandagavi and M.T. Dodamani, 2004. Studies on intercropping of pigeonpea on the growth, yield and economics of rainfed cotton. International symposium on "Strategies for sustainable cotton production -A global vision" 2. Crop production, 2325 November, 2004, University of Agricultural sciences, Dharwad, Karnataka (India): 229-231.

Hallikeri, S.S., H.L. Halemani and R.A. Nandagavi, 2005. Income maximization through trap crop intercropping in rainfed cotton. J. Maharashtra Agric. Univ., 30(1): 21-23.

Hallikeri, S.S., Aladakatti, Y.R. Basanagouda,
C. Patil and S.S. Patil. 2007. Intercropping of cotton with vegetables as the profitable cropping system under rainfed conditions of north Karnataka. University of Agricultural Sciences, Dharwad, Karnataka (INDIA).

Kalyankar, G.K. 2001. Fertilizer management for cotton based cropping system under rainfed condition. M.Sc.(Agric.) Thesis submitted to Marathwada Agriculture University, Parbhani (India).

Khan, M.B., Mahbbob Akhtar and Abdul Khalia. 2001. Effect of planting patterns and different intercropping systems on the productivity of cotton (G. hirsutum) under irrigated condition of Faisalabad. Int. J. Agri. and Soil, 3(4): 432-435.

Khargkharate, V.K., G.L. Kadam, A.D. Pandagale, V.B. Awasarmal and S.S. Rathod. 2014. Studies on kharif legume intercropping with Bt. cotton under rainfed conditions. J. Cotton Res. Dev., 28(2): 243-246.

Mankar, D.D. and S.M. Nawlakhe. 2009. Yield attributes and yield of cotton (main crop) and greengram (intercrop) and quality of cotton as influenced by INM under cotton + greengram intercropping. J. Soils and Crops, 19(2): 315-319.

Murganandan, C.K. 1984. M.Sc. (Ag.) Thesis Tamil Nadu Agric. Univ., Coimbtore, india.

Nandini, S. and V. Chellamuthu. 2004. Relative performance of cotton cultivars under sole and intercropping situation in the coastal region of Karaikal. International symposium on "Strategies for sustainable cotton production - A global vision" 2. Crop Production, 2325 November, 2004, University of Agricultural sciences, Dharwad, Karnataka (India): 235-238.

Nehra, D.S., et al. 1990. J. Cotton Res. Dev., 4(1): 128-129.

Prabukumar, Uthayakumar, B. 2006. Use of 
organics for crops for crop production under rainfed situation-A review. Agric. Rev., 27(3): 208-215.

Raghu Rami Reddy, P. 2005. Planting techniques for intercropping studies in cotton. Ph.D. thesis submitted to Acharya N.G. Ranga Agricultural University.

Raghu Rami Reddy, P. and Shaik Mohammad. 2009. Evaluation of cotton (Gossypium hirsutum) - based intercropping system through different approaches under rainfed conditions. Indian J. Agri. Sci., 79(3): 210-214.

Sanjay, M.T., V.B. Nadagouda, B.T. Pujari, A. Narayangouda and Somshekar. 2003. Intercropping in short duration compact cotton Anjali. Crop Res. Hissar., 26(2): 224-225.

Sankaranarayanan, K., P. Nalayini and C.S. Praharaj. 2012. Multi-tier cropping system to enhance resource utilization, profitablity and sustainability of $\mathrm{Bt}$ cotton (Gossypium hirsutum) production system. Indian J. Agri. Sci., 82(12): 1044-50.

Satish, P. Raja, V. Shaik Mohammad and V. Sailaja. 2012. Effect of intercropping on growth and seed cotton yield yield of Bt. Cotton with different planting patterns. J. Res., ANGRAU. 40(1): 2125.
Shrivastava, G.K., R. Lakpale, P.S. Rathiya, S.S. Bargali. 2010. Effect of nutrient with FYM on biomass production and economics under hybrid cotton-soybean intercropping system. J. Plant Develop. Sci., 2(1): 9-18.

Singh, J., M.V. Venugopalan and N.D. Mannikar. 2000. Soil fertility and crop productivity changes due to cotton based cropping system under rainfed condition. J. Indian Society of Soil Sci., 48(2): 282-287.

Sree Rekha, M., G. Nageswara Rao and S. Dharua. 2008. Effect of legume intercrops on yield and profitability of rainfed cotton in vertisols. J. Cotton Res. Dev., 22: 225-260.

Velmurgan, R., Naik and Vankudhotu Ravinder. 2012. Cotton-Cluster bean intercropping system for better farming, Bioinfolet- A Quarterly. J. Life Sci., 9(4B): 33-34.

Venkataraman, N.S. 2008. Studies on crop diversification through cotton-based intercropping system under rainfed Vertisol. J. Cotton Res. Develop., 22(1): 50-52.

Wankhade, S.T., A.B. Turkhede, V.M. Solanke, S.D. Malvi and R.N. Katkar. 2000. Effect of intercropping and yield of cotton. Cotton Res., 19(3): 409-413.

\section{How to cite this article:}

Ravindra Kumar, A.B. Turkhede, R.K. Nagar and Anil Nath. 2017. Effect of Different Intercrops on Growth and Yield Attributes of American Cotton under Dryland Condition. Int.J.Curr.Microbiol.App.Sci. 6(4): 754-761. doi: https://doi.org/10.20546/ijcmas.2017.604.093 